\title{
Party Polarization and Political Markets: A Model of Electoral Competition and Candidate Positioning
}

\author{
Elizabeth Bergman ${ }^{1, *}$ and Elizabeth M. DeSouza ${ }^{2}$ \\ ${ }^{I}$ Department of Political Science, California State University, USA $;{ }^{2}$ College of Extended Studies, San Diego State \\ University, CA, USA
}

\begin{abstract}
This work gives a theoretical explanation of party polarization in American politics and explains the lack of party convergence as a result of imperfect political competition. We introduce a formal model that demonstrates how convergence occurs only in perfect markets and rarely in American politics. By modifying key Downsian assumptions about the electorate and parties in a two-party system, we derive conclusions that indicate political advantage varies with the composition of the political districts. This alters the range of available positions that a candidate may take (congruent with winning elections) and sheds light on the relationship between local economic trends and political power.
\end{abstract}

Keywords: Parties, voting, congress, elections.

\section{INTRODUCTION}

Perfect markets dominate theoretical explanations of mass behavior, however, imperfect competition governs the real world. In politics this disparity creates a chasm between the expected and the observed. Downs' (1957) seminal model predicts party positions will converge in a two-party system to win centrist votes and elections. However, assumptions in Downs' model raise expectations that are not supported by the empirical record; importantly, most congressional districts are not competitive and political parties do not always modify their ideological positions (especially not in primaries). Previous research has demonstrated that, among political contests for seats in the House of Representatives, candidates of opposing parties tend to take divergent policy positions and divergence occurs more frequently and consistently than the Downs model predicts while convergence is the exception (Ansolabehere et al., 2001).

Party competition is not an isolated event; it involves candidate positioning, electoral behavior, and empirical observations across numerous races; it involves connections between economics, money, skill, experience, and winning elections. As such, scholars (Grofman 1995) have noted that a model of party competition in the U.S. must explain lawmakers voting patterns, regional differences in party control, and the margin of incumbent victory. We would add that a model of party competition should also explain splitticket voting and provide individual-level evidence of economic voting. In this article we revise Downs' central assumptions in order to account for imperfect political markets. By allowing for a full range of possible political market conditions, we can explain why polarization exists in the American two-party system. We do this by showing how candidate positions and vote shares are influenced by local political and economic markets.

*Address correspondence to this author at the Department of Political Science, California State University, USA; Tel: 510-885-3860; Fax: 510885-2477; E-mail: elizabeth.bergman@csueastbay.edu

\section{LITERATURE}

Arguably, there are two ways to model American elections. First, one can assume that voters' positions do not substantively change or differ across districts but that candidates' positions do. Conventional wisdom formalized by Downs follows this model. Given a specific distribution of voter preferences, one can derive specific conclusions about political behavior. The alternative model begins with allowing both the distribution of voters and the candidates' positions to vary. In this scenario, with an infinite array of voter distributions, we are concerned with how a candidates' position will vary. In addition, political competition is not presumed to be perfect: the deciding vote may not be neutral, and candidates may not necessarily chase moderate votes. Both models are subject to simplifying rules and assumptions which produce markedly different conclusions. In evaluating the Downs model, the evidence shows that Senators from the same state but opposing parties do not display position convergence (Grofman, Griffin, and Glazer 1990, Grofman 1995, Volden and Bergman 2006) and findings with respect to economic voting are mixed (see Lewis-Beck Stegmaier 2007 for a comprehensive summary of this extensive literature). In short, party convergence applies to a very narrow range of contests decided by a neutral, non-partisan swing voter. We suggest decoupling the neutral voter from the decisive voter: they are not necessarily one and the same. We argue that the ideological position of the median voter depends on the political-economic characteristics of the local electorate. Three areas are of specific importance to us; 1) the formal ramifications of the local political economy on the candidate's positions, (2) the effects of competitive advantage on incentives for cooperation or noncooperation, and (3) the relationship of policy-oriented position-taking by the candidate as relates to the economy and the electorate.

In addition to district-level political parameters that influence who will win the election, economic characteristics that define the district are equally important. Economic characteristics may include the influence of manufacturing, 
professional services, business, agriculture, natural resource industries, and unemployment on voter opinion. Scholars (Schattschneider 1960; Key 1964) have found linkages between occupational groupings and party allegiance. Influences such as campaign spending or candidate experience also impact political competition, but these are likely to be driven by the underlying probabilities of party success (Jacobson and Kernell 1983, Jacobson 1991). The parties' changing roles in elections and political power may augment or diminish the importance of candidate experience and campaign funds (Aldrich 1995), but even party strength has foundations in local economics. In sum, our theory is that the district's political economy defines the candidate's electoral incentives, the probabilities of success, and the position-taking strategies open to her. Even without deliberate gerrymandering, districts are carved out of communities with distinct economic profiles and long-term political traditions. If the district's political economy underlies the collective decision to vote Democrat or Republican, then most races-whether congressional, state legislative, or county supervisorial-already favor one of the two parties, even before the contest begins.

The argument that most congressional districts are safe seats and not competitive is not new (see, for example, Gelman and King 1990, Abramowitz et al., 2006). More than $90 \%$ of House incumbents seeking re-election routinely win with twenty-point (or greater) margins, and since 1970 the percentage of incumbents winning with $60 \%$ or more of the vote has ranged from a 1994 low of $64.5 \%$ to a 1988 high of $88.5 \%$ (Ornstein et al., 2008). When one considers that single-member districts with winner-take-all rules typically favor the majority party, "all districting is gerrymandering" (Davidson and Oleszek, 2000, 51). The research on safe seats is generally limited to incumbency advantage and an emphasis on institutional barriers to competition (Gelman and King 1990, 1991; Fiorina 1994, 1996; Jacobson 1997) or "home styles" (Mayhew 1974; Fenno 1978; Ansolabehere, Snyder, and Stewart 2000), as opposed to district-specific measures that flow from the political economy. As such, much of the scholarship ${ }^{1}$ in this area evaluates the noneconomic drivers of incumbency advantage, and while noneconomic drivers may react to economic conditions in the sense that political decisions and probabilities of success are influenced by the national economy, competition may be stifled by economic and political opportunities in the state (Ebeid and Rodden 2006). Arguably, then the missing variable in these approaches is district-level economics, and the essential theoretical element is that the position of the median voter is not necessarily neutral and will vary over time and across districts. We address this challenge in the next section.

\section{MODEL SETTING}

We evaluate a game where candidates base their position-taking decisions on (a) obtaining at least fifty percent of the vote, (b) maximizing their ideal policy goals, and (c) building party relationships. These goals are substantiated in the literature (Fenno 1973; Hamilton 2004;

\footnotetext{
${ }^{1}$ For a burgeoning literature on why candidates may not necessarily chase moderate votes see, for example, Eyster and Kittsteiner (2007), Herrera et al., (2008), Ensley (2009) and Zakharov (2009).
}

Penny and Garrett 1996), and the conventional wisdom, as one former House member put it, "[m]embers weigh three goals: they want to make good policy, gain respect inside Congress, and get re-elected (Hamilton, 2004)." These revisions are the basic elements of our formal model, and should apply to all political races in America: ${ }^{2}$

1) The political parties are more different than alike, and sufficiently influential to constrain candidate positiontaking strategies. A party-constraint, whether enforced by party leaders or a byproduct of self-selection, limits the cumulative range of positions that a member may take. $^{3}$

2) The propensity of electing a Democrat or Republican varies across districts and time with the distribution of preferences in the respective electorates. The median voter is not necessarily a neutral voter. ${ }^{4}$

3) Candidates' position-taking strategies are consistent with winning votes, procuring partisan benefits, and staying as true as possible to their ideal policy preferences. The optimum strategy will change over time and districts with the market dynamics of the electorate.

\subsection{Candidates}

Incumbents and challengers have policy preferences that can be mapped on an ideological continuum. One's preferred position $\left(\mathrm{X}_{\mathrm{i}}\right)$ may be located anywhere on the left-right continuum, but the position taken $\left(\mathrm{P}_{\mathrm{i}}\right)$ is subject to two decision rules.

\section{Rule 1}

Advantaged Candidate Strategy. Candidates will take positions consistent with winning re-election and obtaining preferred policies, subject to party constraints and electoral considerations.

\section{Assumption 1a}

Utility Function. A candidate prefers her position to all others (single-peaked preference structure). The utility she obtains from taking a position outside of her ideal point decreases with the distance from her ideal preference. Her utility function can be expressed as:

$$
\mathrm{U}\left(\mathrm{P}_{\mathrm{i}}\right)=-\left(\mathrm{P}_{\mathrm{i}}-\mathrm{X}_{\mathrm{i}}\right)^{2}
$$

where $P_{i}$ is the position she takes in order to win, and $X_{i}$ is her ideal point. ${ }^{5}$

\section{Assumption $1 b$}

Majority-Rule. In order to win the election, a candidate must win fifty percent or more of the votes in a given election. Because winning is a key objective, she will pursue strategies to generate vote share $\left(\mathrm{V}_{\mathrm{i}}\right)$ such that:

$$
\mathrm{V}_{\mathrm{i}} \geq 0.5
$$

\footnotetext{
2 This model follows techniques established by Riker and Ordeshook 1973, and as influenced by others including Shepsle and Bonchek 1997, and Brady and Volden 1998. The model is unidimensional, following Downs (1957), and subsequent findings by Enelow and Hinich (1984), Tanner (1997), and Brady and Volden (1998) that indicate that many dimensions can be collapsed into the party/ideology dimension.

${ }^{3}$ Downs did not use an explicit party constraint in his model, but concedes that existing parties (as opposed to new parties) are "ideologically immobile." (1957, 129).

${ }^{4}$ More often than not, the median voter is a member of the victor's political party.

${ }^{5}$ Note that $\mathrm{P}_{\mathrm{i}} \in\left\{\mathrm{W}_{\mathrm{i}}\right\}$, where $\left\{\mathrm{W}_{\mathrm{i}}\right\}$ is the set of all possible winning positions.
} 


\section{Assumption 1c}

Party Constraint. Position taking is subject to party constraints as follows:

If the candidate is a Democrat: $\mathrm{D}-\mathrm{d} \leq \mathrm{P}_{\mathrm{iD}} \leq \mathrm{D}+\mathrm{d}$

If the candidate is a Republican: $\mathrm{R}-\mathrm{d} \leq \mathrm{P}_{\mathrm{iR}} \leq \mathrm{R}+\mathrm{d}$

If the Republican (R) and Democrat (D) party platforms are points on a left-right continuum, $d$ is some distance from the platform such that points D-d and D+d demarcate the furthest positions that a Democratic candidate can take congruent with her party's major objectives. Similarly, points $R+d$ and $R-d$ represent the furthest positions that a Republican candidate can stray from her party's national platform.

\subsection{Party Constraints}

The model presumes that we have two parties whose platforms may vary over time but are essentially discrete. ${ }^{6}$ In American politics, the Republican Party selects platforms right of neutral, and the Democratic Party chooses platforms left of neutral. Members of each party are constrained to positions within a distance (d) from the national party's platform, such that position taking is limited on the left-right continuum by party boundaries, as depicted in Fig. (1).

$\left.\begin{array}{ccc|cccc}\text { D-d } & \text { D } & \text { D }+d & \text { R-d } & & \text { R } & \text { R+d } \\ \hline \text { [ } & \text { Democratic Party } & \text { ] ] Neutral } & \text { [ } & \text { Republican Party }\end{array}\right]$

Fig. (1). Party Constraints.

The utility function tells us that a candidate derives the greatest utility when the difference between the position she takes $\left(\mathrm{P}_{\mathrm{i}}\right)$ and her preferred position $\left(\mathrm{X}_{\mathrm{i}}\right)$ position is minimized. This function is based on single-peaked preference structures (from Black's 1958 Single-Peakedness Theorem) and two-party majority-rule elections. ${ }^{7}$ We model the party influence as a constraint on members' voting behavior. This is based on findings that the political parties are a relevant force in winning seats and obtaining career benefits (Fowler and McClure 1989; Jacobson 1997). Yet, the constraint need not entail an explicit system of codes, rewards or discipline. The most effective constraints may be self-imposed. Political candidates do not randomly choose to be a Democrat or a Republican: party membership reflects ideologies. Given that the political parties embrace divergent core beliefs, the party constraint may be a result of natural self-selection. If so, the penalty for crossing the line may be higher than depicted here: the values and beliefs that underlie political activism are not easily discarded.

\footnotetext{
${ }^{6}$ The ranges of party-consistent positions do not substantially overlap. This assumption is supported by the distribution of real ADA scores (Groseclose et al., 1996) for House members, when disaggregated by party. Note that the party constraint is not necessary to demonstrate that party convergence toward the ideological center only occurs in perfect political markets. One could evaluate the model without the party constraint and demonstrate that convergence would occur at the point of the median voter, rather than at the center. The party constraint allows the model to identify the equilibria points if party membership has ideological meaning for its candidates. If not, the equilibria points would revert back to the median voter's ideal point rather than a party boundary.

${ }^{7}$ While Assumptions 1a and $1 \mathrm{~b}$ are common in the literature, Assumption 1c adds a significant constraint. For a detailed justification for the party constraint, see Fiorina 1996. For empirical evidence of the party's influence on candidate positioning, see Ansolabehere et al 2001.
}

The significance of the party constraint lays the groundwork for Rule 2, the disadvantaged candidate strategy. It follows from the model that some candidates will not be able to win. This occurs when (1) district configurations favor the other party and (2) party constraints prohibit these candidates from taking positions consistent with capturing the median voter. Candidates whose electoral prospects fall short of winning the seat for these reasons are our disadvantaged players. These candidates want to win, but if they cannot, their secondary motive is to minimize the winner's mandate (Rule 2).

\section{Rule 2}

Disadvantaged Candidate Strategy. If the expected vote share is less than 50\%, incumbents and challengers will pursue strategies aimed solely at maximizing vote share, subject to party constraints (from Assumption 1c).

Rather than staying true to her policy preferences, the underdog will aim for the center. This is consistent with trying to win Black's (1958) "median voter": if the majority of contestable votes are in the center, elections are won or lost in the battle for the median voter. If, however, the median voter's ideal preference is closer to the opponent's party, the winning position is unavailable to the disadvantaged player: party constraints restrict movement.

\section{RESULTS}

Using a uni-dimensional model, where a candidate's ideal position is plotted on the left-right continuum, we derive the position that a candidate will take given every conceivable electoral configuration. For example, what position will a conservative Republican candidate take in a district where a conservative Republican casts the decisive vote? Will this position differ if the median voter is a liberal Democrat? Arguably, it will. For every candidate, there are four possible equilibria positions: (1) his or her ideal position, (2) the moderate party constraint, (3) the extremist party constraint, (4) the win-set boundary. The win-set boundary is the position closest to one's ideal preference that is capable of winning the election. If a candidate's ideal preference is incapable of winning fifty percent of the votes, that member will move to the nearest win-set boundary in order to win the seat.

\subsection{Solving the Candidate Game: Democratic Districts}

Given a district where the median voter's position $\left(\mathrm{M}_{\mathrm{i}}\right)$ is left of the Democratic Party's moderate boundary $\left(\mathrm{M}_{\mathrm{i}} \leq\right.$ $\mathrm{D}+\mathrm{d})$, the incumbent Democrat may expect to win with any position that is closer to the median $\left(\mathrm{M}_{\mathrm{i}}\right)$ than her opponent at $\mathrm{P}_{\mathrm{iR}}$. The theoretical proof follows:

1) $P_{i R}$ will equal R-d (from Rule 2), and

2) four possible equilibria solutions exist for $\mathrm{P}_{\mathrm{iD}}$ :

$$
\begin{aligned}
& \text { A) } \mathrm{P}_{\mathrm{iD}}=\mathrm{X}_{\mathrm{iD}} \text { if }\left\{\begin{array}{l}
(\mathrm{A} . \mathrm{i}) \mathrm{X}_{\mathrm{iD}} \in\{\mathrm{D}-\mathrm{d}, \mathrm{D}+\mathrm{d}\} \text { and } \\
\text { (A.ii) } \mathrm{X}_{\mathrm{iD}} \geq 2 \mathrm{M}_{\mathrm{i}}-\mathrm{R}+\mathrm{d} .
\end{array}\right. \\
& \text { B) } \mathrm{P}_{\mathrm{iD}}=2 \mathrm{M}_{\mathrm{i}}-\mathrm{R}+\mathrm{d} \text { if }\left\{\begin{array}{l}
\text { (B.i) } 2 \mathrm{M}_{\mathrm{i}}-\mathrm{R}+\mathrm{d} \in\{\mathrm{D}-\mathrm{d}, \mathrm{D}+\mathrm{d}\} \text { and } \\
\text { (B.ii) } \mathrm{X}_{\mathrm{iD}}<2 \mathrm{M}_{\mathrm{i}}-\mathrm{R}+\mathrm{d} \text {. }
\end{array}\right.
\end{aligned}
$$

C) $\mathrm{P}_{\mathrm{iD}}=\mathrm{D}+\mathrm{d}$ if $(\mathrm{C} . \mathrm{i}) \mathrm{X}_{\mathrm{iD}}>\mathrm{D}+\mathrm{d}$. 


\section{D) $\mathrm{P}_{\mathrm{iD}}=\mathrm{D}-\mathrm{d}$

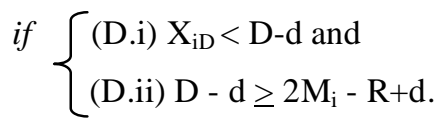

These inequalities tell us that if the candidate is a Republican, she will position herself at the most moderate position consistent with being a Republican. If the candidate is a Democrat, she will select the position most consistent with her preferred policies $\left(\mathrm{X}_{\mathrm{iD}}\right)$ when unconstrained by electoral or party considerations. When her ideal position is too conservative (or liberal) to win the election or collect partisan benefits, she will move to the position nearest her ideal preference that is consistent with both. If her ideal position is outside of the party boundaries, she will move to the closest position within the party platform $(D+d$ if she is more conservative, $\mathrm{D}-\mathrm{d}$ if more liberal than the party). If her ideal position or the nearest party boundary position is inconsistent with winning the election, she will shift to the nearest position among the set of possible winning positions. Relative to her opponent's position, the win-set boundary is at the point equidistant from the median as the Republican party boundary $\left(2 \mathrm{M}_{\mathrm{i}}-\mathrm{R}+\mathrm{d}\right)$. For left-centrist districts, the results are identical to Democratic districts. As illustrated in Fig. (2), the findings will hold for any number of preference distributions where the median voter is left of center.

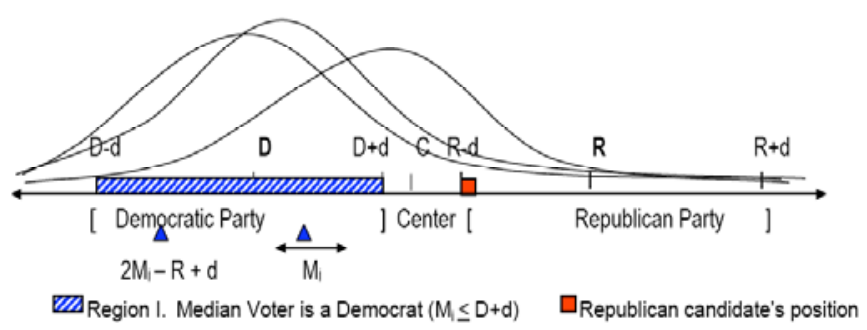

Fig. (2). Equilibria Positions Under Varying Electoral Distributions (Democrat and left-center districts).

Most House members will find that their equilibrium positions are equal to their ideal positions. When this is the case, no moderation is necessary. Congressmembers, Senators and Presidents who face closer elections will be forced to moderate their positions. In close races, the advantaged member's equilibrium position will be equal to the position of the win-set boundary. Both of these scenarios are subject to the party constraint: the equilibrium position must be within the party boundaries. If it is not, the member will take the nearest position congruent with the party platform. Vote shares won and positions taken reflect the interaction of a candidate's true positions, party tolerance, and the political economy.

An example is Pennsylvania's first district, which includes South Central Philadelphia and Chester. This is an urban working-class district with a history of Democratic Party machine politics, no shortage of unskilled labor, and unusually high unemployment rates. Between 1968 and 1996, Democrats were elected in nearly every election, with a mean vote share of $73 \%$. Four different legislators held this seat during this period, all Democrats, and most won reelection with over $65 \%$ of the vote share. ${ }^{8}$ The median

${ }^{8}$ The 1980 election was the only outlier, where a three-way race resulted in the incumbent Democrat losing to an independent by a 3\% margin. The independent candidate,
Democratic vote share (fifteen elections) is .75. The distribution of Democratic vote share (1968-1996) is plotted in Fig. (3a). Members from this district typically voted liberal, with a mean real ADA score of 75.85. ${ }^{9}$

In 1990, the first district's unemployment rate was nearly twice the national average $(6.4 \%)$, at $12.5 \%$; in that year $16.3 \%$ of the population held jobs as operators, fabricators or laborers, and $20.6 \%$ worked in managerial occupations. While fewer than $1 \%$ of the population was employed in farming, forestry or fishing, which is about 0.77 standard deviations below the mean. Retirees account for $12.8 \%$ of the population, or roughly the national mean. ${ }^{10}$ These factors all feed into the distribution of preferences in the electorate where, based on the political leanings of occupational groups (NES Cumulative Data File 1952-1992), Democratic party support should outweigh GOP support. These findings, coupled with the vote share records, suggest that the median voter in District 1 is a Democrat as depicted in Fig. (3b).

\subsection{Solving the Candidate Game for a Republican District}

For right-centrist and Republican districts, the results are symmetrical to those for the Democrat districts. The thirteenth district of Illinois is a good example of a district that tends to produce GOP victories year after year. Five different members held the seat since 1968 - all Republicans. Here, Republicans are expected to win with any party-consistent position they stake out.

District 13 contains Chicago's more upscale white-collar suburbs in DuPage County, along with the southwest section of Cook County and northern Will County; it was considered "one of the most Republican districts in the country" (Duncan and Lawrence, 1997) because during the period 1976 to 1997 Democrats consistently pulled less than $40 \%$ of the congressional vote. ${ }^{11}$ The distribution of Republican vote share (1968-1996) is plotted in Fig. (4a). In 1990, the district was characterized by unusually low unemployment, a larger than average white-collar managerial segment, and very little manual labor. This district is an economic anomaly: on four separate measures (unemployment, retirees, labor, and management), it stands in the statistical tails of the ranked distribution of congressional districts (Winston, Hederman, and Olson 1999). ${ }^{12}$ Survey data suggest that managers and

Thomas Foglietta, won by a $3 \%$ margin in a three-way race, but subsequently ran and won as a Democrat in the next eight elections. His voting record in Congress was consistently liberal, with real ADA scores ranging from 74.88 to 96.44 .

${ }^{9}$ Note that the two charts have reverse axes: Democratic vote shares and ADA scores increase left to right in the boxes, but Democrats are on the left in the typical left-right continuum below.

${ }^{10}$ While the district ranks 167 th among congressional districts in the percentage of people employed in semi-skilled and unskilled labor, it ranks 347 th in the percentage employed as managers. Source for all district- level demographic data: Duncan and Lawrence, 1997; Winston, Hederman and Olson 1999.

${ }^{11}$ In 1996, Susan Hynes (D) pulled $40.1 \%$ of the vote despite being outspent four to one by the incumbent, Harris W. Falwell (R) (Duncan and Lawrence, 1997).

${ }^{12}$ In 1990, unemployment was $3.2 \%$, earning a ranking of 423rd among districts. This unemployment rate was 1.29 standard deviations below the national mean (6.4\%). Only $7.7 \%$ of the population was over sixty-five (1.44 standard deviations below the national mean at $12.5 \%$ ). The district also ranks very low (401st) in the percentage of people employed as operators, fabricators or laborers $(8.5 \%$, about half the $15.2 \%$ mean). As for farming, forestry and fishing, the district ranks 410 th, with only $0.5 \%$ of the population employed in this sector ( 0.85 standard deviations from the mean which is at $2.6 \%$ ). However, the district ranks 30th when it comes to management positions, with an unusually large proportion of the people in this line of work $(36.1 \%)$. This represents 1.61 standard deviations above the mean $(25.9 \%)$ (Winston, Hederman and Olson 1999). 

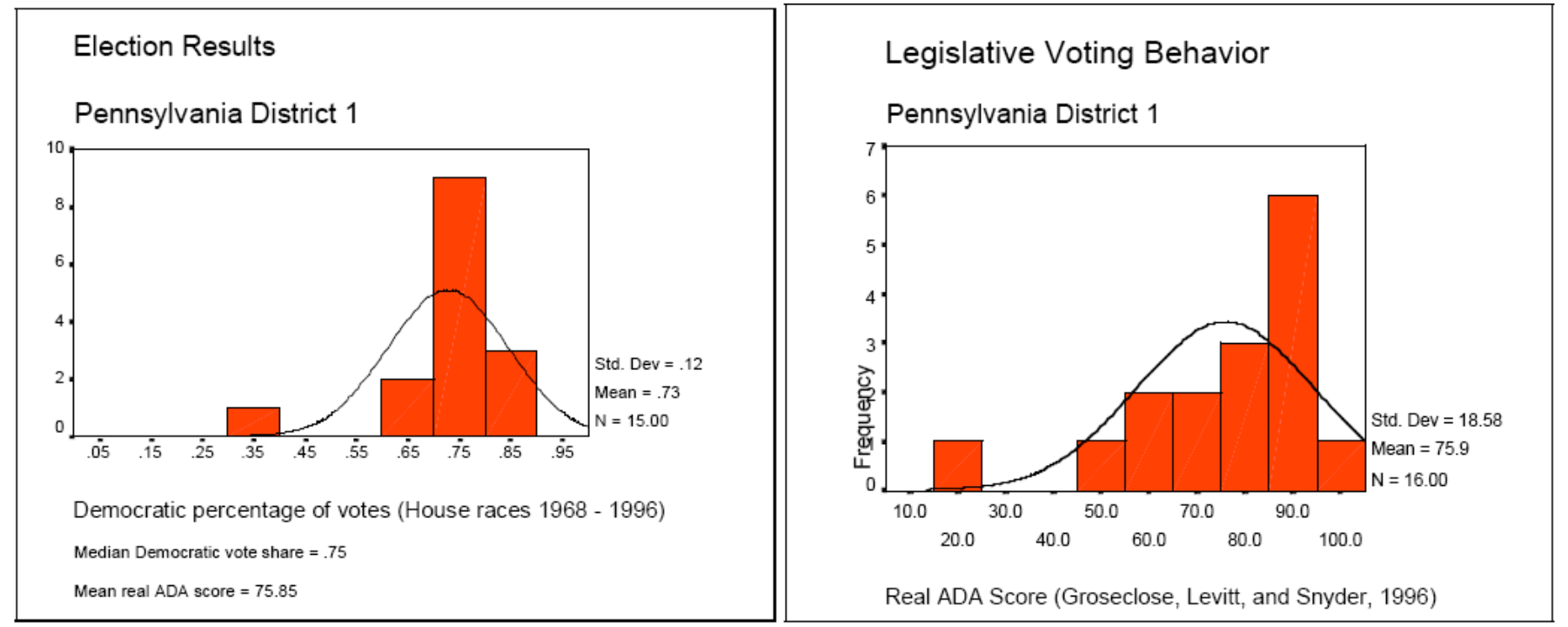

Fig. (3a). Pennsylvania District 1: Election Results and Legislative Voting Record 1968-96.

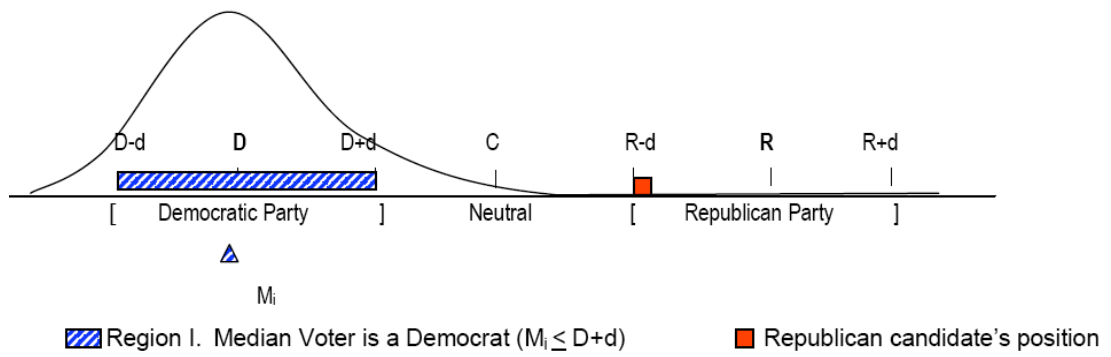

Fig. (3b). Median Voter Democrat.
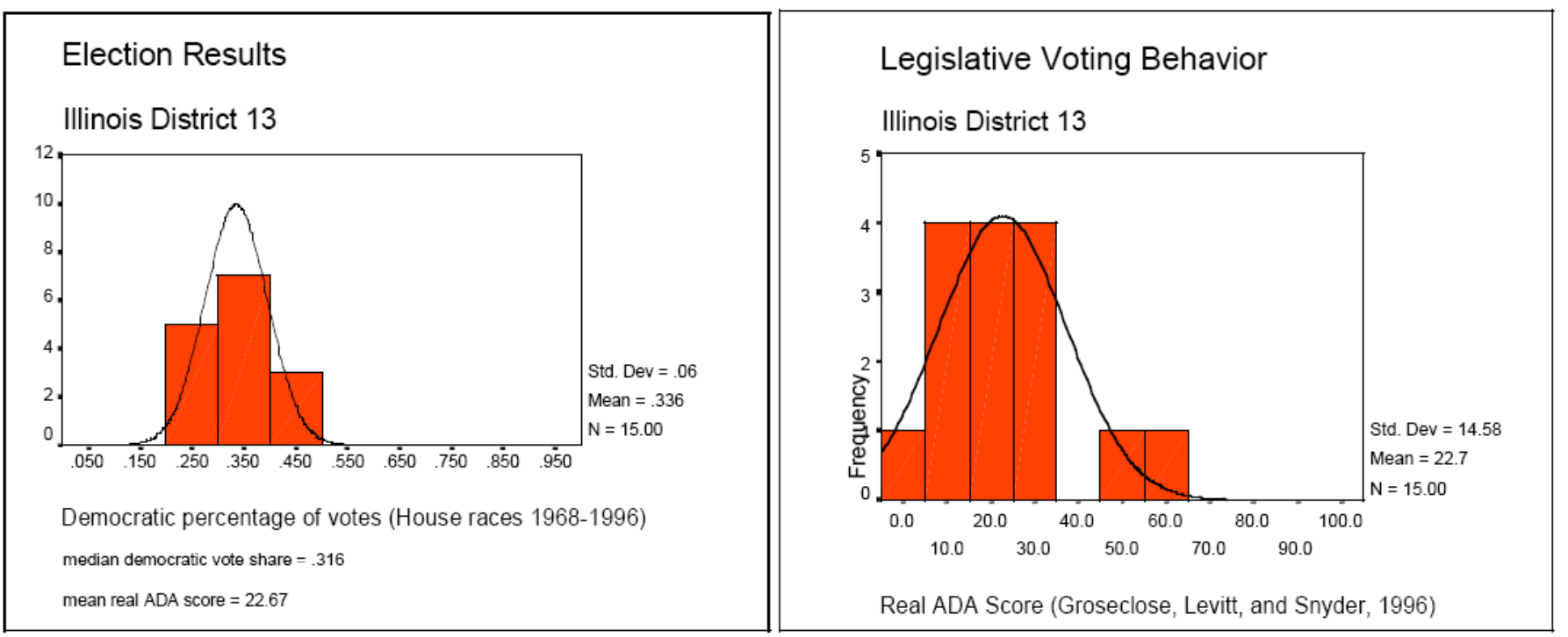

Fig. (4a). Illinois District 13: Election Results and Legislative Voting Record 1968-96.

professionals tend to favor the Republican Party (NES Cumulative Data File 1952-1992). All else equal, the large proportion of income derived from the managerial sector would suggest that the district will lean Republican.

As illustrated in Fig. (4b), in Republican districts, the median voter's position $\left(\mathrm{M}_{\mathrm{i}}\right)$ lies right of the Republican
Party's moderate boundary, such that $\mathrm{M}_{\mathrm{i}} \geq \mathrm{R}-\mathrm{d}$. Given this situation, the Democrat candidate will maximize votes by taking position $\mathrm{D}+\mathrm{d}$. The Republican can win the election by taking any position between $\mathrm{R}-\mathrm{d}$ and $2 \mathrm{M}_{\mathrm{i}}-\mathrm{D}-\mathrm{d}$, and may prefer a conservative position. The results obtained in rightcentrist districts are identical to those obtained in Republican 


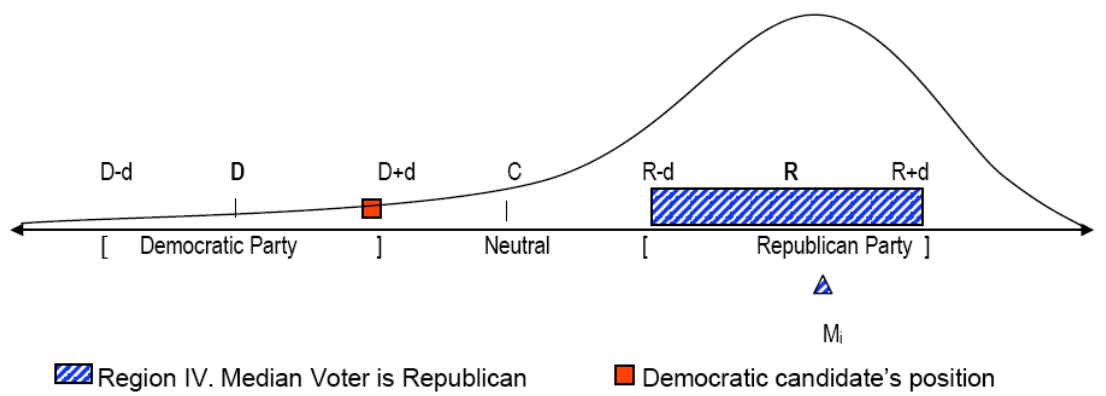

Fig. (4b). Median Voter Republican.

districts. For a right-centrist or Republican district, the equilibria solutions would mirror the results for the Democratic and left-centrist districts.

Complete convergence will only occur when party constraints are breached. This leads to an unexpected conclusion: convergence in a two-party system is a special case of the economic equilibrium model. Downs demonstrated that party convergence is not likely to occur in multi-party systems. ${ }^{13} \mathrm{We}$ demonstrate that convergence is also unlikely to occur in a two-party system. From the proofs above, partial convergence will only occur when the median voter is at dead-center. Competition, or the lack of it, is at the heart of this phenomenon.

\subsection{General Expectations}

1) The model anticipates four general characteristics about vote shares:

a) Incumbent House members will usually win with margins greater than ten points. This is because most districts are not decided by a neutral, nonpartisan median voter.

b) Incumbent House members' vote shares will vary with shifts in the median, unless those shifts are met with compensatory revisions in position.

c) Incumbent House members' vote shares may also change in the event that the member takes positions further from the median than in a previous year (even if the median does not move or moves in the direction of the incumbent's party).

d) A candidate will win with fifty percent of the vote share when either $(i)$ the median voter is at the point of neutrality in the ideological distribution, or (ii) the advantaged member takes a position at the outermost win-set boundary (equidistant from the median voter as the challenger's party constraint).

2) The model also gives us specific expectations about vote share and candidate strategy:

a) As the expected margin of victory increases, the diversity of preference positions in the win-set increases. In safe seats, where the incumbent party wins on a regular basis, advantaged-party

\footnotetext{
${ }^{13}$ Fewer than $1.3 \%$ of elections are contested at dead-center (50\% vote share). These findings suggest that convergence to neutrality will not occur in $86.4 \%$ to $98.7 \%$ of House elections ( $\mathrm{N}=6,485,1968-1996)$.
}

candidates may win elections with nearly any position.

b) As the expected margin of victory decreases, the diversity of preference positions in the win-set decreases. Those members whose ideal preferences are outside the new win-set will moderate their positions.

c) Changes in the median will affect the positiontaking strategy of any incumbent whose ideal position is outside of the win-set. The members of Congress affected by the win-set constraint include all incumbents whose (i) ideal (or selected) positions are outside the win-set ${ }^{14}$ and (ii) any incumbents whose ideal position may have been inside the win-set in the last election, but whose district has changed significantly enough in the interim to shift the nearest win-set boundary closer to the challenger's position.

d) When the median voter is neither Democrat nor Republican (as indicated by ten point or smaller vote share margins), candidates will take positions at their respective moderate party boundaries. ${ }^{15}$

3) Not all median shifts will result in comparable shifts in candidate positions. Only movements into or across the point of neutrality will generate shifts in candidate positions. Intermediate shifts in the median position will, however, affect (a) which positions are within the win-set, and (b) vote shares. As the median moves toward neutrality, most members can hold onto their seats or vote margins by moderating their positions accordingly. The only exception is those members whose positions are already at the party's moderate boundary.

4) Specific shifts in the median will produce dramatic change in candidat positions. Movement of the median voter across the point of neutrality exerts significant effects on position-taking equilibria. If the median shifts from left-of-center to right-of-center, Democrats will respond by moving right to the moderate party

\footnotetext{
${ }^{14}$ The distinction between ideal and selected positions differentiates between candidates whose preferred positions are outside the win-set and candidate's whose preferred position may be within the win-set, but for one reason or another selected a position outside the district's win-set boundary.

${ }^{15}$ Not all races that result in ten point or smaller margins are decided by a neutral median voter. As noted in item 1(d), an incumbent in a Democratic (Republican) district may take a position at the outermost win-set boundary and win the race with a bare majority ( $50 \%$ of the vote) even when a the decisive vote is cast by a Democrat (Republican).
} 
boundary, and Republicans, whose positions were previously moderated, will respond by also moving right. A median shift from right-of-center to left-ofcenter will trigger a symmetrical effect.

5) Economic conditions will affect the position of the median voter in specific ways. The economic properties of the district vary considerably with the location of the median voter.

a) The position of the median voter is a function of the distribution of preferences in the electorate. This distribution is largely determined by the economic profile of the district.

b) Economic change is the chief determinant of biennial shifts in the median voter's position, and differential change across districts and states.

c) When economic change is significant enough to shift the position of the median voter (across, into, or out of the point of neutrality), it is expected to alter the position-taking dynamics of the district. These types of position movements apply to legislators who previously received near fifty percent of the vote.

d) Position movement will depend on a member's ideal point, the party constraint, the magnitude of the net median shift, and the distribution of preferences in the economic cohorts affected by economic change.

e) Changes in the size and importance of weakly aligned economic cohorts in the electorate will exert a lesser influence on vote shares and position-taking dynamics than equivalent changes that affect strongly aligned economic groups.

6) Position-convergence only occurs under specific circumstances. Partial position convergence, where both parties converge to the moderate party boundaries is a special case of the model, and occurs in fewer than $14.6 \%$ of the 1968 through 1996 cases when the median voter is neutral. $^{16}$

a) Full position convergence to the median voter will not occur in a two-party system. ${ }^{17}$

b) Specific shifts in the median will determine whether the parties converge or diverge. If the median shifts from partisan to neutral, position-taking strategies will shift from the advantaged strategy toward the

\footnotetext{
${ }^{16}$ Between 1968 and 1996, 14.6\% of House races $(\mathrm{N}=6,485)$ were decided with margins of ten or fewer points. Given that the percentage of voters who do not lean toward one of the two parties is consistently less than ten percent [NES Cumulative Data File 1952-1992, five-point party identification scale], races that are decided by greater than ten points are decided by people who identify with one of the major parties. A race that results in fifty percent vote share indicates that the candidates' positions were equidistant from the median voter. This can occur through convergence or through advantaged candidates taking positions on the outermost win-set boundary. The formal proofs demonstrate that any arrangement where the median voter is left of center produces identical results to an electoral arrangement where the median voter is a Democrat. Similarly, a right-of-center median voter produces identical equilibria solutions as a Republican median voter. The only cases where both parties are expected to converge to the party boundaries are those where the race is decided by a margin of ten or fewer points, and the median voter is neutral.

${ }^{17}$ This is due to the assumption that the party constraint prevents full convergence. The only exception is when the two-party system is in a transition from a period of noncompetitive one-party politics. In this case, the convergence is due not to the properties of the two-party system, but to special properties of single-party politics. This explains the convergence we observe in Southern formerly Confederate states.
}

disadvantaged (Rule 2), where vote-maximization is the sole criterion. Similarly, if the median shifts from neutral to partisan, position-taking will shift away from limited convergence: the advantaged candidate will move closer to his or her ideal preference. The disadvantaged candidate will remain at the party constraint.

7) Dramatic shifts in the median will produce specific results. Movement of the median position into or across the point of neutrality will generate (a) a parallel shift of the candidates as opposed to the convergence expectation in the Downsian model, and (b) seat turnover.

8) Split-ticket districts or mid-term seat losses are produced when positions taken by a House or presidential candidate are outside the win-set. Splitticket voting or mid-term seat loss by the President's party will result when specific conditions are satisfied. Note that none of these scenarios is contingent on policy-moderating behavior on the part of the electorate:

a) The incumbent legislator takes a winning position, but the presidential candidate of her party takes a position outside the win-set. Result: the incumbent legislator's party will win the House seat, but not the district's presidential vote.

b) The incumbent legislator takes a position inconsistent with winning, but the median, which has not shifted, still favors her party. Result: the incumbent legislator's party will win the district's presidential vote but not the House seat.*

c) The district median has shifted from Democrat to left-centrist (or Republican to right-centrist) such that the incumbent legislator's position is no longer in the win-set (for example a liberal Democrat or conservative Republican), and she does not revise her position. Result: the incumbent legislator's party may win the district's presidential vote with a more moderate party-consistent position, but not the House seat.*

d) The district median has shifted toward the incumbent legislator's party, but, inconsistent with the model, her position shifts even further left (or right). As with item a, the incumbent legislator's position is outside the win-set, although the district median favors the incumbent member's party. Result: identical to item a.*

* Items marked with an asterisk involve extra-model position taking. ${ }^{18}$

A similar explanation pertains to midterm seat loss by the President's party. The midterm "correction" occurs when: $(i)$ the economic equilibrium in the districts shift away from the party of the President, and the incumbent representative of the same party fails to revise his or her voting patterns. Result: President's party loses seats in these districts; or (ii) the median has not shifted, but the incumbent legislator's position changes in such a way as to place him or her outside

\footnotetext{
${ }^{18}$ Extra-model positions are those that violate one or both of the candidate game rules, and may arise out of uncertainty, misjudgment, or obstinacy.
} 
the win-set (as in casting votes too liberal or conservative for the district); or (iii) the median shifts in favor of the party of the President, and the incumbent representative of the same party shifts too far in the same direction (to a location outside the district win-set). ${ }^{19}$

None of the propositions generated by the model rely on individual voters making economic assessments: voters may vote for any reason that they choose. Only the distribution of voter preferences in the electorate is important to the collective vote decision.

\section{CONCLUSIONS}

Several conclusions can be drawn from this analysis. First, goal-oriented candidates who seek to obtain their preferred policies, cultivate influence within their parties, and win elections will take differing strategies depending on the electoral conditions. Second, because most congressional districts heavily favor one party for long periods, the advantaged candidate will often find that his or her ideal preferences will win elections. In these cases, no convergence toward the political center is necessary or expected. Third, where political competition is discouraged (through districting rules or decisions that favor one party), sharp political rivalries are encouraged. No matter how far to the center the disadvantaged candidate will move, the advantaged candidate will not reciprocate. Advantaged candidates will move further to the extremes with higher vote shares, until they have reached their ideal preference points. Fourth, there are very few conditions where party convergence will occur. These conditions include presidential elections and a few Senate and House elections where the electorate is sufficiently diverse and the race is sufficiently close such that the independent voter is the pivotal voter. Finally, candidates may bend to the wishes of their electorates but only as necessary to secure and retain office.

If we model party competition as a continuum (instead of assuming perfect competition), our conclusions about position-taking strategy are quite different from those generated from traditional models. The most obvious finding is that candidates who win elections with reasonable margins may vote any way that they please: they have no incentive to take the middle ground and every reason to stand by their policy ideals. A less obvious conclusion is that party vote shares will vary systematically with changes in the economic profile of the district. This phenomenon occurs because (a) incumbents tend to stand by their positions, but (b) the ideological position of the median voter in a district varies from year to year. Moreover, district-level economics matter: when political outcomes and behavior are directly influenced by local economics, sudden changes in the economy may produce dramatic political events. Finally, the model explains why presidential and congressional elections may produce different outcomes-even in the same year or district.

Traditional rational choice models view party competition as a game where winning is the primary objective. We have argued that the primary objective is

\footnotetext{
${ }^{19}$ Note that all of these options require extra-model position taking.
}

maximizing one's policy ideals. However, position taking is not solely subject to one's personal preferences: candidates must win elections in order to maintain political power. Nevertheless, winning and party allegiance are secondary to achieving one's ideal policy goals. The economic properties of the district underlie whether a member may vote her ideals or must moderate her positions. Subject to party constraints:

1) When districts are drawn such that the economic profile clearly favors the incumbent's party, the incumbent's equilibrium position is at his or her ideal preference position.

2) When district economic profiles produce a neutralmedian electorate, the incumbent must moderate his or her position to a point consistent with winning (subject to party constraints).

In these ways, a legislator's decision to vote her ideal preferences hinges on the position of the median voter. The position of the median voter depends on the distribution of preferences in the electorate. The political and economic properties of the district continually re-define this distribution of preferences.

\section{ACKNOWLEDGEMENT}

None declared.

\section{CONFLICT OF INTEREST}

None declared.

\section{METHODOLOGY APPENDIX}

\section{Formal Proofs}

\section{Proof A}

1. From Assumption 2, $\mathrm{P}_{\mathrm{iR}}=\mathrm{R}-\mathrm{d}$.

2. From Assumption $1 b, V_{D} \geq 0.5$ when $\left|R-d-M_{i}\right|>\mid P_{i D}-$ $\mathrm{M}_{\mathrm{i}}$.

This holds for all $P_{i D} \geq 2 M_{i}-R+d$ when $M_{i}$ is in region $I$.

3. From Assumption 1a, $U\left(P_{i D}\right)=-\left(P_{i D}-X_{i D}\right)^{2}$

To maximize utility:

$$
\begin{aligned}
& \text { Max } U_{i D}=-\left(P_{i D}-X_{i D}\right)^{2} \\
& P_{i D}
\end{aligned}
$$

Taking the partial derivative of $\mathrm{U}_{\mathrm{iD}}$ with respect to $\mathrm{P}_{\mathrm{iD}}$ :

$\underline{\partial \mathrm{U}_{\mathrm{iD}}}=\quad-2\left(\mathrm{P}_{\mathrm{iD}}-\mathrm{X}_{\mathrm{iD}}\right)$

$\partial \mathrm{P}_{\mathrm{iD}}$

Solving for zero, we get:

$$
-2\left(\mathrm{P}_{\mathrm{iD}}-\mathrm{X}_{\mathrm{iD}}\right)=0 \quad \Rightarrow \quad \mathrm{P}_{\mathrm{iD}}=\mathrm{X}_{\mathrm{iD}}
$$

This result is subject to two constraints, plotted in Fig. (5) below:

$$
\begin{aligned}
& \text { A.i) } X_{i D} \in\{D-d . . D+d\} \text { and } \\
& \text { A.ii) } X_{i D} \geq 2 M_{i}-R+d \text {. }
\end{aligned}
$$

As long as the median voter $\left(\mathrm{M}_{\mathrm{i}}\right)$ is within the Democratic party's platform region, a Democrat may win with any position within the platform that is closer to $M_{i}$ than the opponent at R-d. In cases where condition (A.i) is not 


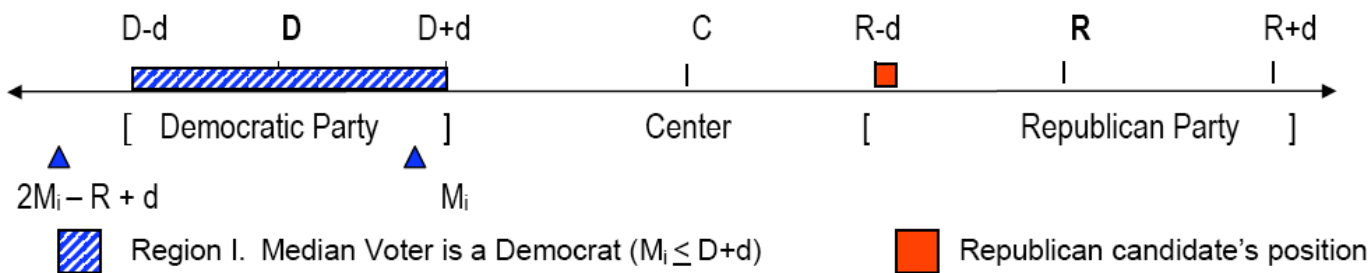

Fig. (5). Proof A.

met, equilibria will occur at the party constraint (D-d or $\mathrm{D}+\mathrm{d})$ per Assumption 1c, except in cases where condition (A.ii) is not met, equilibria will occur at a point equidistant from the median $\left(\mathrm{M}_{\mathrm{i}}\right)$ as $\mathrm{P}_{\mathrm{iR}}$, per Assumption $1 \mathrm{~b}$.

\section{Proof B}

1) From Assumption $1 b, V_{D}$ must be greater than or equal to 0.5 .

2) In order to win fifty or more percent of the vote, the Democrat incumbent must take a position $\left(\mathrm{P}_{\mathrm{iD}}\right)$ such that $\left|\mathrm{P}_{\mathrm{iD}}-\mathrm{M}_{\mathrm{i}}\right|<\left|\mathrm{P}_{\mathrm{iR}}-\mathrm{M}_{\mathrm{i}}\right|$.

3) Let $\mathrm{P}_{\mathrm{iD}} *$ be the position equidistant from the median as $\mathrm{P}_{\mathrm{iR}}$, such that:

$\left|\mathrm{P}_{\mathrm{iD}} *-\mathrm{M}_{\mathrm{i}}\right|=\left|\mathrm{P}_{\mathrm{iR}}-\mathrm{M}_{\mathrm{i}}\right|$

Substituting $\{\mathrm{R}-\mathrm{D}\}$ for $\mathrm{P}_{\mathrm{iR}}$ and solving for $\mathrm{P}_{\mathrm{iD}} *$ :

$\mathrm{P}_{\mathrm{iD}} * 2 \mathrm{M}_{\mathrm{i}}-\mathrm{R}+\mathrm{d}$

4a. If $\mathrm{X}_{\mathrm{iD}}<2 \mathrm{M}_{\mathrm{i}}-\mathrm{R}+\mathrm{d}$, then $\mathrm{V}_{\mathrm{D}}<0.5$. Therefore, from Assumption $1 \mathrm{~b}$, the incumbent whose ideal position $\mathrm{X}_{\mathrm{iD}}$ is within party constraints but further from the median than her opponent $\mathrm{P}_{\mathrm{iR}}$, must take a position $\mathrm{P}_{\mathrm{iD}}$ such that $\mathrm{P}_{\mathrm{iD}} \geq 2 \mathrm{M}_{\mathrm{i}}-\mathrm{R}+\mathrm{d}$.

4b. If $\mathrm{X}_{\mathrm{iD}} \leq \mathrm{D}-\mathrm{d}<2 \mathrm{M}_{\mathrm{i}}-\mathrm{R}+\mathrm{d}$, the expected vote share $\left(\mathrm{V}_{\mathrm{D}}\right)$ is again less than 0.5. In this case, the Democrat incumbent's ideal position is left of the Democratic Party's liberal boundary, but a move to the boundary position is insufficient to win greater than fifty percent of the votes. From Assumption 1b, the incumbent must take a position $\mathrm{P}_{\mathrm{iD}}$ such that $\mathrm{P}_{\mathrm{iD}} \geq 2 \mathrm{M}_{\mathrm{i}}-\mathrm{R}+\mathrm{d}$.

5. From results $4 \mathrm{a}$ and $4 \mathrm{~b}$, provided that $\mathrm{X}_{\mathrm{iD}} \leq \mathrm{D}+\mathrm{d}$, the incumbent Democrat will take a position $\mathrm{P}_{\mathrm{iD}} \geq 2 \mathrm{M}_{\mathrm{i}}$ $\mathrm{R}+\mathrm{d}$. Yet, by Assumption 1a, all points greater than (right of) $2 \mathrm{M}_{\mathrm{i}}-\mathrm{R}+\mathrm{d}$ will have decreasing utility for the incumbent whose ideal point is left of $2 \mathrm{M}_{\mathrm{i}}-\mathrm{R}+\mathrm{d}$. Therefore, the utility-maximizing incumbent will arrive at position $\mathrm{P}_{\mathrm{iD}}=2 \mathrm{M}_{\mathrm{i}}-\mathrm{R}+\mathrm{d}$.

This result holds as long as two conditions are met: $\mathrm{R}+\mathrm{d}$.

(B.i) $2 \mathrm{M}_{\mathrm{i}}-\mathrm{R}+\mathrm{d} \in\{\mathrm{D}-\mathrm{d}, \mathrm{D}+\mathrm{d}\}$ AND (B.ii) $\mathrm{X}_{\mathrm{iD}}<2 \mathrm{M}_{\mathrm{i}}-$

Here, any Democratic member with preferred positions left of $2 \mathrm{M}_{\mathrm{i}}-\mathrm{R}+\mathrm{d}$, must move to $2 \mathrm{M}_{\mathrm{i}}-\mathrm{R}+\mathrm{d}$ or risk losing the election.

\section{Proof C}

1) From Assumption 1c, if the candidate is a Democrat, party constraints apply such that:

$\mathrm{D}-\mathrm{d} \leq \mathrm{P}_{\mathrm{iD}} \leq \mathrm{D}+\mathrm{d}$
2) If the member's ideal position $X_{\mathrm{iD}}$ is more conservative than the Democratic Party's moderate boundary (D+d), the member must take a position $\mathrm{P}_{\mathrm{iD}} \leq \mathrm{D}+\mathrm{d}$.

3) From Assumption 1a, all positions left of (less than) $\mathrm{D}+\mathrm{d}$ will result in decreasing utility, therefore equilibrium will result at $\mathrm{P}_{\mathrm{iD}}=\mathrm{D}+\mathrm{d}$.

This result holds given the following constraint:

C.i) $X_{i D}>D+d$

\section{Proof D}

1) From Assumption 1c, if the candidate is a Democrat, party constraints apply such that:

$\mathrm{D}-\mathrm{d} \leq \mathrm{P}_{\mathrm{iD}} \leq \mathrm{D}+\mathrm{d}$

2) If the member's ideal position $X_{i D}$ is more liberal than the Democratic Party's liberal boundary (D-d), the member must take a position $\mathrm{P}_{\mathrm{iD}} \geq \mathrm{D}-\mathrm{d}$.

3) From Assumption 1a, all positions right of (greater than) D-d will result in decreasing utility, therefore equilibrium will result at $\mathrm{P}_{\mathrm{iD}}=\mathrm{D}-\mathrm{d}$.

This result holds for all cases where constraints D.i and D.ii are present:

$$
\text { D.i) } \mathrm{X}_{\mathrm{iD}}<\mathrm{D}-\mathrm{d} \text { AND D.ii) } \mathrm{D}-\mathrm{d} \geq 2 \mathrm{M}_{\mathrm{i}}-\mathrm{R}+\mathrm{d} \text {. }
$$

\section{REFERENCES}

Abramowitz, I.A., Alexander, B., \& Gunning, M. (2006). Incumbency, Redistricting, and the Decline of Competition in U.S. House Elections. The Journal of Politics, 68, 75-88.

Aldrich, J. H. (1995). Why Parties? The Origin and Transformation of Political Parties in America. Chicago: University of Chicago Press.

Ansolabehere, S., Snyder, Jr., J.M., \& Stewart III, C. (2001). Candidate Positioning in U.S. House Elections. American Journal of Political Science, 45(1), 136-159.

Ansolabehere, S., Snyder, Jr., J.M., \& Stewart III, C. (2000). Old Voters, New Voters, and the Personal Vote: Using Redistricting to Measure the Incumbency Advantage. American Journal of Political Science, 44(1), 17-34.

Black, D. (1958). The Theory of Committees and Elections. Cambridge: Cambridge University Press.

Brady, D.W., \& Volden, C. (1998). Revolving Gridlock, San Francisco: Westview Press.

Cox, G.W., \& McCubbins, M.D. (1993). Legislative Leviathan: Party Government in the House. Berkeley: University of California Press.

Davidson, R.H., \& Oleszek, W. (2000). Congress and Its Members. $7^{\text {th }}$ Ed. Washington, DC: Congressional Quarterly Press. CQ Incorporated.

Downs, A. (1957). An Economic Theory of Democracy, New York: HarperCollins Publishers.

Duncan, P.D., \& Lawrence, C.C. (1997). Politics in America 1998: The $105^{\text {th }}$ Congress. Washington, DC: CQ Press.

Ebeid, M., \& Rodden, J. (2006). Economic Geography and Economic Voting: Evidence from the US States. British Journal of Political Science, 36(3), 527-547.

Enelow, J.M., \& Hinich, M.J. (1984). The spatial theory of voting: An introduction. Cambridge: Cambridge University Press. 
Ensley, J.M. (2009). Individual Campaign Contributions and Candidate Ideology. Public Choice, 138, 221-238.

Erikson, R.S. (1989). Economic conditions and the presidential vote. American Political Science Review, 83, 567-73.

Erikson, R.S. (1990). Economic conditions and the congressional vote: a review of the macrolevel evidence. American Journal of Political Science, 34, 373-99.

Eyster, E., \& Kittsteiner, T. (2007). Party Platforms in Electoral Competition with Heterogeneous Constituencies. Theoretical Economics, 2, 41-70.

Fenno, Jr., R.F. (1973). Congressmen in Committees. Boston: Little, Brown and Company Inc.

Fenno, Jr., R.F. (1978). Homestyle: House Members in Their Districts. Boston: Little Brown.

Fiorina, M.P. (1981). Retrospective Voting in American National Elections. New Haven: Yale University Press.

Fiorina, M.P. (1994). Divided Government in the American States: A Byproduct of Legislative Professionalism. American Political Science Review 88, 304-316.

Fiorina, M.P. (1996). Divided Government. $2^{\text {nd }}$ Ed. Boston: Allyn and Bacon.

Fowler, L.L., \& McClure, R.D. (1989). Political Ambition: Who Decides to Run for Congress. New Haven: Yale University Press.

Gelman, A., \& King, G. (1990). Estimating incumbency advantage without bias. American Journal of Political Science, 34(4), 1142-1164.

Gelman, A., \& King, G. (1991). Systematic consequences of incumbency advantage in U.S. House elections. American Journal of Political Science, 35, 110-138.

Grofman, B., Griffin, R., \& Glazer, A. (1990). Identical Geography, Different Constituencies, See What a Difference Party Makes. In R.J. Johnston, F. Shelley, \& P. Taylor (Eds.) Developments in Electoral Geography, (pp. 207-220). London: Croom Helm.

Grofman, B. (1995). Toward an Institution-Rich Theory of Political Competition with a Supply Side Component. In Bernard Grofman (Ed.). Information, Participation, and Choice: An Economic Theory of Democracy in Perspective, (pp. 179-193). Ann Arbor: The University of Michigan Press.

Groseclose, T., Levitt, S., \& Snyder, Jr., J.M. (1996). An Inflation Index for ADA Scores. Manuscript, Massachusetts Institute of Technology.

Groseclose, T., Levitt, S., \& Snyder, Jr., J.M. (1999). Comparing interest group scores across time and chambers: adjusted ADA scores for the U.S. Congress. American Political Science Review, 93(1), 33-50.

Hamilton, L.H. (2004). How Congress Works and Why You Should Care. Indiana University Press.
Herrera, J., Levine, D.K., \& Martinelli, C. (2008). Platforms, Campaign Spending and Voter Participation. Journal of Public Economics, 92(34), 501-513.

Jacobson, G.C. (1997). The Politics of Congressional Elections, $4^{\text {th }}$ Ed. New York: Longman.

Jacobson, G.C. (1991). The Economy in U.S. House Elections. In Norpoth, H., Lewis-Beck, M.S., \& Lafay, J.D. (Eds.). Economics and Politics: The Calculus of Support (pp. 44-47) Ann Arbor: University of Michigan Press.

Jacobson, G.C., \& Kernell, S. (1983). Strategy and Choice in Congressional Elections. $2^{\text {nd }}$ Ed. New Haven: Yale University Press.

Key, Jr., V.O. (1964). Politics, Parties, and Pressure Groups. $5^{\text {th }}$ Ed. New York: Thomas Y. Crowell Co.

Lewis-Beck, M.S. (1988). Economics and Elections: The Major Western Democracies. Ann Arbor: University of Michigan Press.

Lewis-Beck, M.S., \& Stegmaier, M. (2007). Economic Models of the Vote, in: Russell Dalton \& Hans-Dieter Klingemann (Eds). The Oxford Handbook of Political Behavior (pp. 518-37). Oxford: Oxford University Press.

Mayhew, D.R. (1974). Congress: The Electoral Connection. New Haven: Yale University Press.

Ornstein, N.J., Mann, T.E., \& Malbin, M.J. (2008). Vital Statistics on Congress 2008. Washington, DC: The Brookings Institution.

Penny, T.J., \& Garrett, M. (1996). Common Cents. New York: Avon Books.

Poole, K.T., \& Rosenthal, H. (1985). A Spatial Model for Legislative Roll Call Analysis. American Journal of Political Science 29, 357-84.

Poole, K.T., \& Rosenthal, H. (1996). Congress: A Political-Economic History of Roll Call Voting. Oxford: Oxford University Press.

Riker, W.H., \& Ordeshook, P.C. (1973). An Introduction to Positive Political Theory. Englewood Cliffs, NJ: Prentice Hall.

Schattschneider, E.E. (1960). The Semisovereign People, New York: Harcourt Brace Jovanovich.

Shepsle, K.A. \& Bonchek, M.S. (1997) Analyzing Politics, New York: W.W. Norton Co.

Tanner, T. (1997). An analysis of voter predictive dimensions and recovery of underlying issue space. Public Choice, 93, 315-334.

Volden, C., \& Bergman, E. (2006). How Strong Should Our Party Be? Party Member Preferences Over Party Cohesion. Legislative Studies Quarterly, 31(1), 71- 103.

Winston, D., Hederman, R., \& Olson, C. (1999). The Congressional District Ranking Book. Retrieved on: November 21, 2002, from http://www.heritage.org/cd_ranking.

Zakharov, A.V. (2009). A Model of Candidate Location with Endogenous Valence. Public Choice, 138, 347-66.

Received: June 09, 2011

Revised: November 05, 2011

Accepted: November 11, 2011

(C) Bergman and DeSouza; Licensee Bentham Open.

This is an open access article licensed under the terms of the Creative Commons Attribution Non-Commercial License (http://creativecommons.org/licenses/by-nc/3.0/) which permits unrestricted, non-commercial use, distribution and reproduction in any medium, provided the work is properly cited. 